Check for updates

Cite this: RSC Adv., 2017, 7, 23714

Received 10th January 2017

Accepted 17th April 2017

DOI: $10.1039 / c 7 r a 00277 g$

rsc.li/rsc-advances

\section{Four-stage biofilm anaerobic-anoxic-oxic-oxic system for strengthening the biological treatment of coking wastewater: COD removal behaviors and biokinetic modeling}

\begin{abstract}
Xin Zhou, (D)*ab Zeqian Zhang ${ }^{\mathrm{a}}$ and Yaxin $\mathrm{Li}^{\mathrm{a}}$
High-strength coking wastewater with a high chemical oxygen demand (COD) was efficiently treated by a novel pilot-scale four-stage biofilm anaerobic-anoxic-oxic-oxic (FB- $\mathrm{A}^{2} / \mathrm{O}^{2}$ ) system. The results demonstrated that the system played an important role in obtaining an overall COD removal efficiency at a hydraulic detention time (HRT) of $116 \mathrm{~h}$ and over $60 \%$ of COD was removed in $\mathrm{A}_{2}$ and $\mathrm{O}_{1}$ reactors. Three different mathematical models, including the Grau second-order model, modified Stover-Kincannon model, and the Monod-biological contact oxidation model (Monod-BCO model) were applicable to describe the COD removal efficiency of the $\mathrm{FB}-\mathrm{A}^{2} / \mathrm{O}^{2}$ system. Based on a kinetics study and model evaluation, the Monod-BCO model was demonstrated to be more applicable to COD removal from the system with an average determination coefficient of 0.9661 . According to the Monod-BCO model, the COD maximum utilization rates for a unit area of carrier for the $A_{1}, A_{2}, O_{1}$, and $O_{2}$ units were $0.1685 \mathrm{~g}$

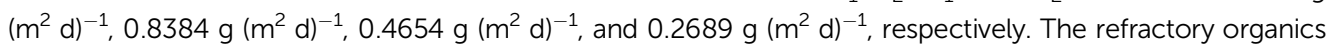
in each reactor were further evaluated by the Monod-BCO model. The results proved that the system had great potential for treating high-COD coking wastewater. Step-feeding after the $A_{1}$ reactor was strongly suggested to further optimize the feeding pattern of the system, depending on the model evaluation.
\end{abstract}

\section{Introduction}

Coking wastewater generated from coking, coal gas purification, liquefaction, and the refining of coal by-products at coke plants ${ }^{1}$ usually contains a large amount of complicated organic compositions, thus endangering natural water bodies and threatening ecological environment and even impacting human health. ${ }^{2}$ For biodegradable organic contaminants, the conventional activated sludge (CAS) process is considered to be an environmental friendly and low-cost option. ${ }^{3,4}$ However, compositions of coking wastewater are ordinarily complicated and can involve many diverse bio-inhibitory organic compounds, such as long-chain alkanes, nitrogen heterocyclics (NHCs), and polycyclic aromatic hydrocarbons (PAHs), ${ }^{\mathbf{1 , 5}, \mathbf{6}}$ which are major obstacles for removing the oxygen-consuming substances responsible for the chemical oxygen demand (COD) by the CAS process. Moreover, toxic inhibition from these bio-refractory organic substances frequently leads to poor bioactivity, the difficulty of sludge settling, and weak resistance to loading shocks of the CAS system..$^{7-10}$ Therefore, the effluent COD of coking wastewater can

${ }^{a}$ College of Environmental Science and Engineering, Taiyuan University of Technology, Taiyuan 030024, P. R. China. E-mail: zhouxin@tyut.edu.cn; Tel: +86-0351-6079557

${ }^{b}$ State Key Laboratory of Urban Water Resources and Environment, Harbin Institute of Technology, Harbin 150090, P. R. China easily fail to meet the Emission Standard of Pollutants for the Coking Chemical Industry (GB 16171-2012). ${ }^{11}$

The above problems can be efficiently solved by biofilm systems since attached bio-reactors provide a favorable living environment by offering a higher volume loading rate, longer cell retention time, and more biomass than suspended sludge. ${ }^{\mathbf{1 2 - 1 5}}$ Recently, a lot of attached-growth bio-reactors have been identified as desirable and steady systems suitable for treating refractory organic coking wastewater..$^{\mathbf{1 2 , 1 6 - 2 1}}$ However, anaerobic and anoxic stages are indispensable for degrading organic matters combined with aerobic degradation. Therefore, we successfully developed a novel pilot-scale four-stage anaerobic-anoxic-oxicoxic $\left(\mathrm{FB}-\mathrm{A}^{2} / \mathrm{O}^{2}\right)$ system for treating coking wastewater based on the principle of the multi-stage mixed degradation of organics. ${ }^{22}$ Unlike other biological treatments, the total system consists of four separate biofilm compartments, which are arranged in sequence to favorably treat coking wastewater due to the combination of pre-anaerobic, anoxic and two aerobic processes for organic mineralization. The final effluent COD was improved to a value of less than $100 \mathrm{mg} \mathrm{L}^{-1}$, thus meeting the strict national coking wastewater discharge standards of China. ${ }^{22}$

Kinetic modeling is considered to be a feasible and convenient approach to deeply understand the removal performance, predict effluent concentration, and to optimize the biological process. ${ }^{23,24}$ Various models have been reported in previous studies for 
evaluating the biodegradation kinetics in different kinds of treatments of various wastewaters. The Grau second-order substrate removal model involving only the influents, effluent concentration, and the hydraulic detention time (HRT) was applied to evaluate COD removal from poultry slaughterhouse wastewater ${ }^{25}$ and cassava starch wastewater. ${ }^{26}$ The Monod model was used to describe the microbial growth at first. ${ }^{27}$ Afterward, it could be described well for assessing the kinetic characteristics of pollutant biodegradation. ${ }^{28-32}$ The Monod-biological contact oxidation model (Monod-BCO model) was modified by the Monod model. ${ }^{33}$ Besides describing the biodegradation kinetics, the total area of carriers and the concentration of refractory organics were also introduced as variables in the model. The Stover-Kincannon model originates from describing biomass in a rotating biological contactor $^{34}$ and according to previous reports it is capable of predicting substrate removal for different wastewaters treated by a biofilm reactor. ${ }^{35-41}$ Different from the Monod model, the modified Stover-Kincannon model introduces the COD loading rate $\left(Q S_{\mathrm{i}} / V\right)$ to the model and simplifies it by not requiring other hard-to-measure parameters. Until now, however, a dynamics model for COD removal of coking wastewater in the aspect of microbial kinetics was still missing. ${ }^{23,42}$ Apart from this, the treatability and biodegradation potential of COD removal in each unit of the multi-stage process needs to be more deeply understood.

In the present study, the effects of the organic loading rate (OLR) OLR on overall COD removal and its removal proportion in each reactor of the total system were investigated. Also, in contrast to other studies analyzing the kinetics of coking wastewater using a single model, ${ }^{\mathbf{2 3 , 4 2}}$ three different mathematical models, including the Grau second-order model, the modified Stover-Kincannon model, and the Monod-biological contact oxidation model (Monod-BCO model), were applied to establish a more simplified and practical mathematical model for assessing the kinetics of COD removal in our four-stage FB$\mathrm{A}^{2} / \mathrm{O}^{2}$ system for treating coking wastewater. Finally, optimizing suggestions for process improvement were further put forward based on biokinetic analysis and model comparisons.

\section{Materials and methods}

\subsection{COD removal in each reactor}

The schematic diagram of the pilot-scale $\mathrm{A}^{2} / \mathrm{O}^{2}$ biofilm system was presented in our previous study. ${ }^{22}$ The characteristics of raw coking wastewater were shown in Table 1 . The configuration of the $\mathrm{A}^{2} / \mathrm{O}^{2}$ system used for COD mass balance is also presented in Fig. 1. The amount of COD removal in each unit was calculated in accordance with eqn (1)-(4):

Table 1 Wastewater characterization of raw coking wastewater

\begin{tabular}{ll}
\hline Parameters & Values \\
\hline $\mathrm{pH}$ & $7.5-8.5$ \\
$\mathrm{COD}\left(\mathrm{mg} \mathrm{L}^{-1}\right)$ & $900-1800$ \\
$\mathrm{BOD}_{5}\left(\mathrm{mg} \mathrm{L}^{-1}\right)$ & $200-370$ \\
$\mathrm{Ammonium} \mathrm{nitrogen}_{\left(\mathrm{mg} \mathrm{L}^{-1}\right)}$ & $150-330$ \\
$\mathrm{BOD}_{5} / \mathrm{COD}$ & $0.20-0.28$
\end{tabular}

$$
\text { COD removal in } \mathrm{A}_{1} \text { reactor }=Q\left(C_{\mathrm{A}_{1}}-C_{\mathrm{in}}\right)
$$

COD removal in $\mathrm{A}_{2}$ reactor $=Q\left[\left(C_{\mathrm{A}_{1}}-C_{\mathrm{A}_{2}}\right)+R\left(C_{\mathrm{O}_{2}}-C_{\mathrm{A}_{2}}\right)\right]$

$$
\begin{aligned}
& \text { COD removal in } \mathrm{O}_{1} \text { reactor }=Q(1+R)\left(C_{\mathrm{O}_{1}}-C_{\mathrm{A}_{2}}\right) \\
& \text { COD removal in } \mathrm{O}_{2} \text { reactor }=Q(1+R)\left(C_{\mathrm{O}_{2}}-C_{\mathrm{O}_{1}}\right)
\end{aligned}
$$

\subsection{Substrate removal kinetics}

2.2.1 Grau second-order substrate removal model. The second-order model could be expressed via eqn (5): ${ }^{43}$

$$
-\frac{\mathrm{d} S}{\mathrm{~d} t}=k_{1} X\left(\frac{S_{\mathrm{e}}}{S_{0}}\right)^{2}
$$

Eqn (6) was obtained as follows by integrating and linearizing from eqn (5):

$$
\frac{S_{0} \mathrm{HRT}}{S_{0}-S_{\mathrm{e}}}=\frac{S_{0}}{k_{1} X}+\mathrm{HRT}
$$

where $k_{1}$ is a constant of the second-order model $\left(\mathrm{d}^{-1}\right)$ and $X$ means the biomass concentration in the reactor $\left(\mathrm{g} \mathrm{L}^{-1}\right)$. When the term $\frac{S_{0}}{k_{1} X}$ is expressed as a constant $a$, the following equations of eqn (7) and (8) can be derived:

$$
\begin{gathered}
\frac{S_{0} \mathrm{HRT}}{S_{0}-S_{\mathrm{e}}}=a+b \mathrm{HRT} \\
\frac{\mathrm{HRT}}{E}=a+b \mathrm{HRT}
\end{gathered}
$$

where the values of the constant $b$ and $a=S_{0} /\left(k_{1} X\right)^{\mathbf{4 4}}$ are obtained from plotting HRT/ $E$ against HRT, while $E$ acts as the ammonium nitrogen removal efficiency (\%).

2.2.2 Modified Stover-Kincannon model. The modified Stover-Kincannon model has been successfully used to determine the kinetic parameters in various attachedgrowth reactors for treating different kinds of wastewater. $^{36,38-41}$ The maximal COD removal rate in the $\mathrm{FB}-\mathrm{A}^{2} / \mathrm{O}^{2}$ system can be predicated from the modified Stover-Kincannon model at steady state, using the formula illustrated below:

$$
\frac{\mathrm{d} S}{\mathrm{~d} t}=\frac{Q\left(S_{0}-S_{\mathrm{e}}\right)}{V}
$$

Furthermore, the modified Stover-Kincannon model can also be represented as: ${ }^{45}$

$$
\frac{\mathrm{d} S}{\mathrm{~d} t}=\frac{U_{\mathrm{m} 1}\left(Q S_{0} / V\right)}{k_{2}+Q S_{0} / V}
$$

So, it can be converted to the following equation:

$$
\left(\frac{\mathrm{d} S}{\mathrm{~d} t}\right)^{-1}=\frac{V}{Q\left(S_{0}-S_{\mathrm{e}}\right)}=\frac{k_{2} V}{U_{\mathrm{m} 1} Q S_{0}}+\frac{1}{U_{\mathrm{m} 1}}
$$




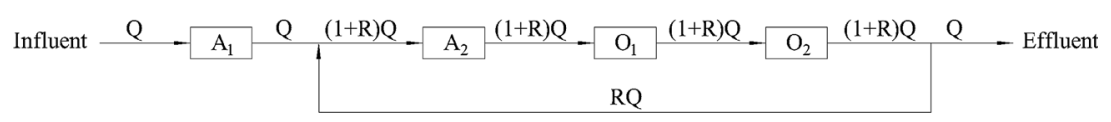

Fig. 1 Schematic diagram of the pilot-scale $A^{2} / O^{2}$ biofilm system $\left(A_{1}\right.$ : anaerobic reactor; $A_{2}$ : anoxic reactor; $O_{1}$ : first oxic reactor; $O_{2}$ : second oxic reactor; $Q$ : flow rate of the influent; $R$ : nitrifying recirculation ratio).

where $U_{\mathrm{m} 1}$ is the constant maximal substrate removal rate $(\mathrm{kg}$ $\left.\left(\mathrm{m}^{3} \mathrm{~d}\right)^{-1}\right)$ and $k_{2}$ means the saturation rate constant $\left(\mathrm{kg}\left(\mathrm{m}^{3}\right.\right.$ $\left.\mathrm{d})^{-1}\right)$. The means of the other parameters are represented the same as before.

2.2.3 Monod-biological contact oxidation model. A dynamic model of bio-contact oxidation, based on Monod's equation, can be used to provide a prediction for the degradation of COD in this system. According to $\mathrm{Hu}$ et al., ${ }^{33}$ the substrate consumption in the reactor is satisfied by the following equation according to the material balance:

$$
\left(-\frac{\mathrm{d} S}{\mathrm{~d} t}\right) V=Q S_{0}-\left[\left(-\frac{\mathrm{d} S}{\mathrm{~d} t}\right)_{\mathrm{A}} \times V_{\mathrm{A}}+\left(-\frac{\mathrm{d} S}{\mathrm{~d} t}\right)_{\mathrm{S}} V_{\mathrm{S}}+Q S\right]
$$

where $(-\mathrm{d} S / \mathrm{d} t)_{\mathrm{S}}$ and $(-\mathrm{d} S / \mathrm{d} t)_{\mathrm{A}}$ are the removal rates of suspended cells and attached cells $\left(\mathrm{kg}\left(\mathrm{m}^{3} \mathrm{~d}\right)^{-1}\right)$, respectively, $V_{\mathrm{A}}$ is the volume of attached biofilm $\left(\mathrm{m}^{3}\right)$, and $V_{\mathrm{S}}$ is the liquid volume in the reactor $\left(\mathrm{m}^{3}\right)$.

In this study, the kinetic study of two-step biofilm aerobic systems was at the period of steady state. The suspended cells accounted for in the biofilm reactors were much lower than the attached ones and the suspended cells could be ignored. Thus, eqn (12) could be written as:

$$
0=Q S_{0}-\left[\left(-\frac{\mathrm{d} S}{\mathrm{~d} t}\right)_{\mathrm{A}} \times V_{\mathrm{A}}+Q S\right]
$$

Furthermore, the substrate removal rate by the attached cells could be calculated by the biofilm cells' absolute growth rate $(\mathrm{d} x / \mathrm{d} t)_{\mathrm{A}}$ and its theoretical yield coefficient $Y_{\mathrm{A}}$ :

$$
\left(-\frac{\mathrm{d} S}{\mathrm{~d} t}\right)_{\mathrm{A}}=\left(\frac{\mathrm{d} x}{\mathrm{~d} t}\right)_{\mathrm{A}} \times \frac{1}{Y_{\mathrm{A}}}=\frac{\frac{(\mathrm{d} x / \mathrm{d} t)_{\mathrm{A}}}{X_{\mathrm{A}}} X_{\mathrm{A}}}{Y_{\mathrm{A}}}=\frac{\mu_{\mathrm{A}} X_{\mathrm{A}}}{Y_{\mathrm{A}}}
$$

Then:

$$
Q\left(S_{0}-S_{\mathrm{e}}\right)=\frac{\mu_{\mathrm{A}} X_{\mathrm{A}}}{Y_{\mathrm{A}}} N A D
$$

where $N$ means the volume of carriers in the fixed biofilm reactor $\left(\mathrm{m}^{3}\right)$ and $A$ is the surface area of the carriers $\left(\mathrm{m}^{2} \mathrm{~m}^{-3}\right)$.

Furthermore, as one of the empirical models for simulating microbial growth, the Monod model ${ }^{27}$ has been proven to be applicable for bio-contact oxidation: ${ }^{33}$

$$
\frac{\mathrm{d} S}{\mathrm{~d} t}=\frac{\mu_{\mathrm{max}} S_{\mathrm{e}}}{k_{3}+S_{\mathrm{e}}}
$$

Eqn (16) can be deduced as below:

$$
Q\left(S_{0}-S_{\mathrm{e}}\right)=\frac{X_{\mathrm{A}}}{Y_{\mathrm{A}}} \times N A D \times \frac{\mu_{\max } S_{\mathrm{e}}}{k_{3}+S_{\mathrm{e}}}
$$

The removal rate in a unit area of carrier is $\left(\mathrm{g} \mathrm{m}^{-2} \mathrm{~d}^{-1}\right)$ :

$$
\begin{gathered}
U=\frac{Q\left(S_{0}-S_{\mathrm{e}}\right)}{N A}=\frac{U_{\mathrm{m} 2} S_{\mathrm{e}}}{k_{3}+S_{\mathrm{e}}} \\
\frac{1}{U}=\frac{N A}{Q\left(S_{0}-S_{\mathrm{e}}\right)}=\frac{1}{U_{\mathrm{m} 2}}+\frac{k_{3}}{U_{\mathrm{m} 2}} \frac{1}{S_{\mathrm{e}}}
\end{gathered}
$$

When $S_{\mathrm{e}} \ll k_{3}$, eqn (18) could be transformed as:

$$
U=\frac{U_{\mathrm{m} 2} S_{\mathrm{e}}}{k_{3}}=K S_{\mathrm{e}}
$$

where $\mu_{\mathrm{A}}$ and $\mu_{\max }$ are recognized as the specific growth rate of the attached biofilm and the maximum specific growth rate $\left(\mathrm{d}^{-1}\right)$, respectively. $K=\frac{U_{\mathrm{m} 2}}{k_{3}}$, while $U_{\mathrm{m}}=\frac{\left(\mu_{\mathrm{max}}\right)_{\mathrm{A}} X_{\mathrm{A}} D}{Y_{\mathrm{A}}}$ is the maximum substrate removal rate per area of carrier $\left(\mathrm{g} \mathrm{m}^{-2} \mathrm{~d}^{-1}\right)$, and $k_{3}$ is the half-saturation concentration $\left(\mathrm{mg} \mathrm{L}^{-1}\right)$.

When non-biodegradable harmful compounds exist in the wastewater, the concentration of decomposition bio-refractory substances $\left(S_{\mathrm{n}}\right)$ should be reduced. The equation considering the refractory substance could be converted by eqn (18) and (19):

$$
\begin{gathered}
U=K\left(S_{\mathrm{e}}-S_{\mathrm{n}}\right) \\
\frac{1}{U}=\frac{N A}{Q\left(S_{0}-S_{\mathrm{e}}\right)}=\frac{1}{U_{\mathrm{m} 2}}+\frac{k_{3}}{U_{\mathrm{m} 2}} \frac{1}{S_{\mathrm{e}}-S_{\mathrm{n}}}
\end{gathered}
$$

\subsection{Analytical methods}

The temperature, $\mathrm{pH}$, dissolved oxygen (DO), and alkalinity in the influent and effluent samples in each reactor were analyzed on a daily basis, while $\mathrm{COD}, \mathrm{NH}_{4}{ }^{+}-\mathrm{N}$, and $\mathrm{NO}_{3}{ }^{-}-\mathrm{N}$ were measured weekly. The measurements of $\mathrm{COD}, \mathrm{NH}_{4}{ }^{+}-\mathrm{N}, \mathrm{NO}_{3}-\mathrm{N}$, and alkalinity were determined according to the standard methods. ${ }^{46}$ Temperature and $\mathrm{pH}$ were monitored by a $\mathrm{pH}$ meter (WTW Multi340i). The value of DO was monitored via a portable DO meter (YSI-500).

\section{Results and discussion}

\subsection{Effect of OLR on overall COD removal}

The impact of the COD loading rate $\left(Q S_{0} / V\right)$ (OLR) from the pilot-scale $\mathrm{A}^{2} / \mathrm{O}^{2}$ biofilm system along with the effluent COD concentration and its removal efficiency are depicted in Fig. 2. As the figure shows, the general trend of COD removal efficiency increased as the COD load increased from $0.1 \mathrm{~kg}\left(\mathrm{~m}^{3} \mathrm{~d}\right)^{-1}$ to $0.25 \mathrm{~kg}\left(\mathrm{~m}^{3} \mathrm{~d}\right)^{-1}$, but then obviously decreased with the increasing OLR. The value of effluent COD decreased to 


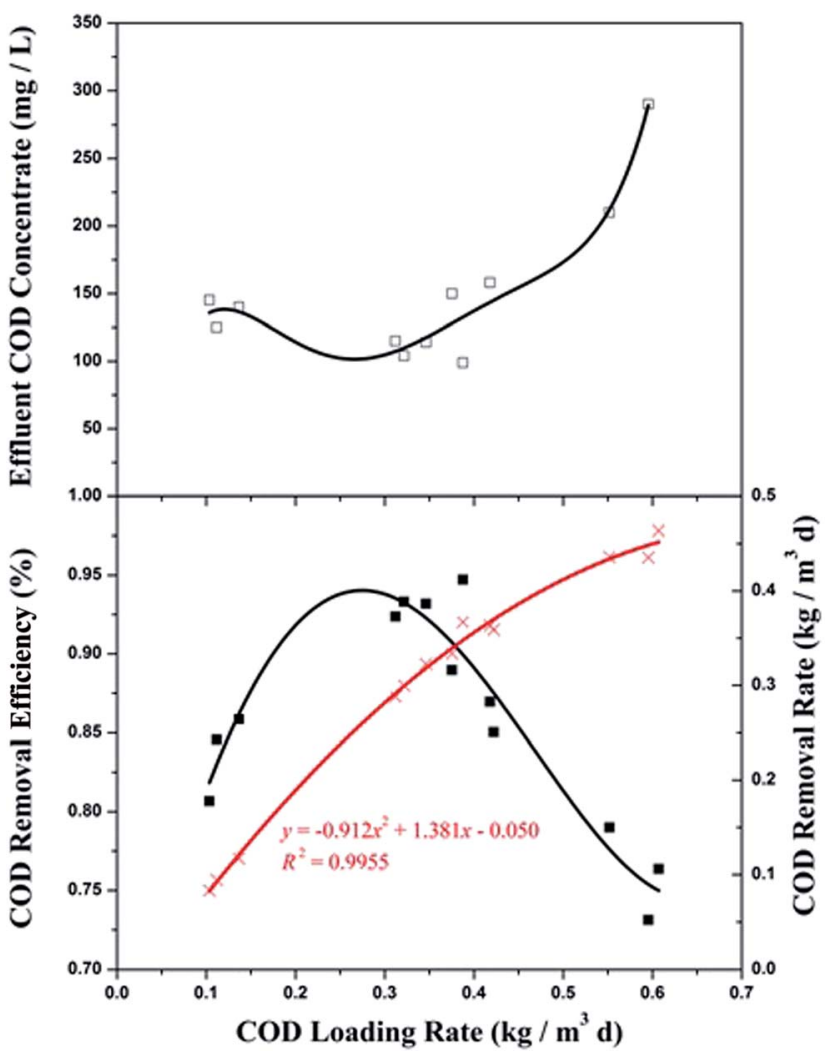

Fig. 2 Variation of effluent COD concentration, COD removal efficiency, and COD removal rate at different OLRs. ( $\square$ ) Effluent COD concentration; ( $\mathbf{\square})$ COD removal efficiency; $(x)$ COD removal rate.

$98 \mathrm{mg} \mathrm{L}^{-1}$, with a maximum COD removal efficiency of $92.3 \%$ at an optimized OLR of $0.25 \mathrm{~kg} \mathrm{~m} \mathrm{~m}^{-3} \mathrm{~d}^{-1}$. The effluent COD was able to meet the requirements of the Emission Standard of Pollutants for Coking Chemical Industry (GB 16171-2012) and the final effluent COD concentration in this study was lower than that in other related studies (Table 2).

For a high level of OLR (over $0.38 \mathrm{~kg} \mathrm{~m}^{-3} \mathrm{~d}^{-1}$ ), the COD removal efficiency decreased dramatically from $90 \%$ to $73.1 \%$, while the effluent COD concentration accordingly increased considerably. The lower COD removal efficiency indicated that the attached microorganisms could not flourish at a higher level of OLR. One possible reason for this was that the biofilm could have become detached by the strong hydraulic shear at a high level of OLR. On the other hand, the bioactivity of the microorganisms was restrained by some refractory organics accumulated at lower HRT.
The results of the trends of the COD removal rate in the different OLRs indicated that the COD removal rate rapidly increased with the increase in COD loading rate. A high correlation coefficient $\left(R^{2}=0.9955\right)$ was obtained between the COD loading rate and the COD removal rate, fitting well for the quadratic function. This implied that the total system had a distinguished capability for organics removal. As a high OLR was obtained, the tendency of the COD removal rate gradually became flat, implying that the COD removal rate of the system had reached its threshold. The optimum COD loading rate seemed within the range of $0.175 \mathrm{~kg}\left(\mathrm{~m}^{3} \mathrm{~d}\right)^{-1}$ to $0.380 \mathrm{~kg}\left(\mathrm{~m}^{3}\right.$ d) ${ }^{-1}$ at a HRT of $116 \mathrm{~h}$.

\subsection{Effect of OLR on the COD removal in each reactor}

In order to investigate the COD removal behavior within the whole system, the contribution ratio of each bioreactor in the overall COD removal efficiency at various organic loadings was determined and the results are shown in Fig. 3. As indicated in the figure, the OLR also had a significant impact on COD removal efficiency, either on the overall removal efficiency or the COD removal distribution in each reactor. In the $\mathrm{A}_{1}$ reactor, the average COD removal proportion of the total COD removal was close to $20 \%$. An excessively high or low OLR increases the COD removal efficiency in the anaerobic reactor. Yet, as a pretreatment unit, instead of removing biodegradable COD,

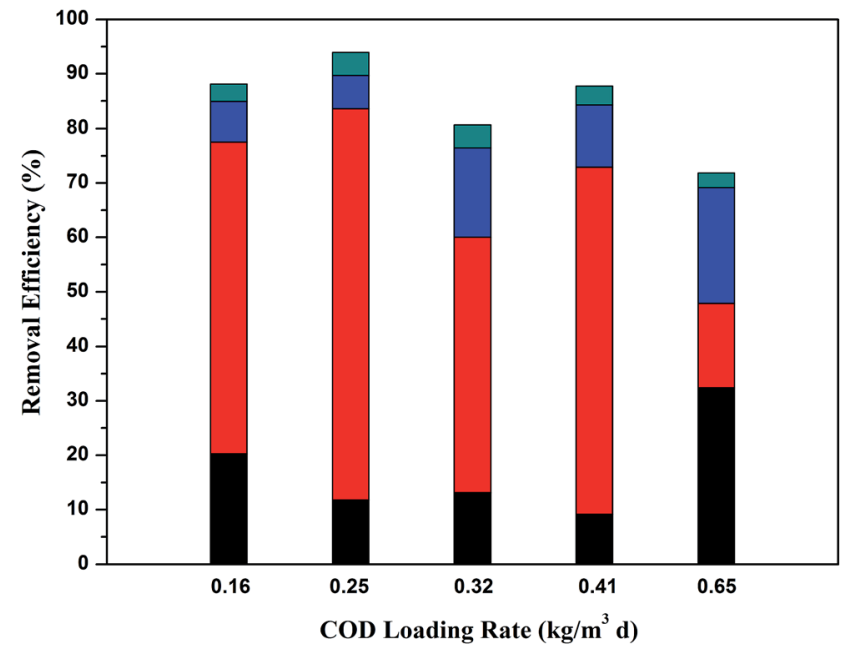

Fig. $3 \mathrm{COD}$ removal ratio of $\mathrm{FB}-\mathrm{A}^{2} / \mathrm{O}^{2}$ systems at different OLRs $\left(\omega C O D\right.$ removal in the $A_{1}$ reactor; $-C O D$ removal in the $A_{2}$ reactor; $=C O D$ removal in the $O_{1}$ reactor; $=C O D$ removal in the $O_{2}$ reactor).

Table 2 Comparison of COD removal in coking wastewater by various processes

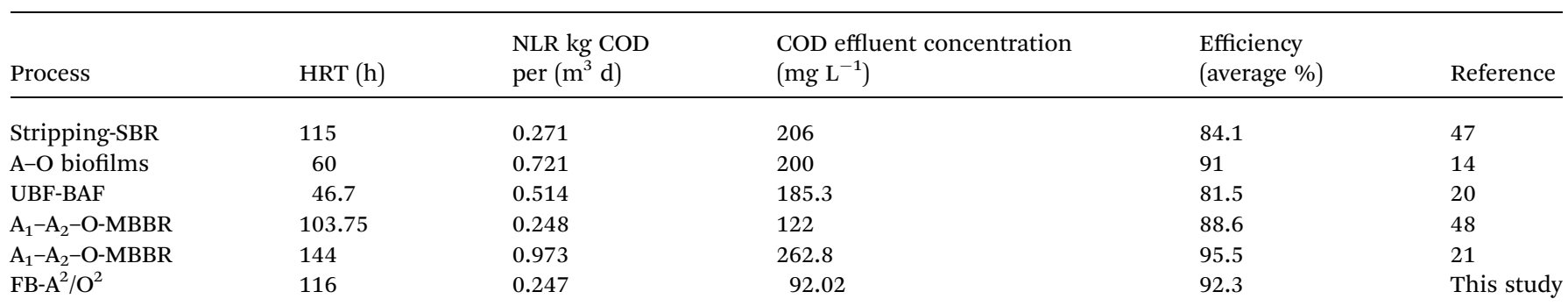


the main purpose of the anaerobic reactor was to enhance the biodegradability of the wastewater for partial rupturing and transforming some macromolecular structures, such as PAHs and heterocyclic compounds into the alkyl, acetic acid, and other long-chain organics and low molecular fatty acids.9,20,49 Thus, a moderate range of OLR was maintained to enhance the COD removal efficiency in the subsequent anoxic and two aerobic stages.

For the $\mathrm{A}_{2}$ reactor, the anoxic unit contributed greatly to the total COD removal efficiency at lower OLR, especially within the range of $0.25 \mathrm{~kg} \mathrm{~m}^{-3} \mathrm{~d}^{-1}$ to $0.41 \mathrm{~kg} \mathrm{~m}^{-3} \mathrm{~d}^{-1}$, in which the removal efficiency of COD could reach over $60 \%$. Such a higher removal efficiency of COD was also reported by Zhang et al. ${ }^{9}$ and Sahariah et al. ${ }^{21}$ An excessively high COD loading rate would not be suitable for the anoxic degradation of COD due to an incomplete HRT.

For the two-step aerobic reactors, the COD removal efficiency was always higher in the $\mathrm{O}_{1}$ reactor than in the $\mathrm{O}_{2}$ reactor. The probable reason for this was that the molecular products converted by the anaerobic and anoxic stages were preferentially utilized and degraded throughout the $\mathrm{O}_{1}$ reactor. Thus, the remaining COD compositions entering the $\mathrm{O}_{2}$ reactor were biorefractory organics, which led to its lower COD removal efficiency. Furthermore, the calculated data showed that the COD removal efficiency in the two aerobic units at a COD loading rate of $0.65 \mathrm{~kg}\left(\mathrm{~m}^{3} \mathrm{~d}\right)^{-1}$ was higher than at the lower correlation coefficient of 0.9461 was obtained, confirming a closer fit for predicting COD removal of the $\mathrm{A}_{1}$ unit in this study. For the use of the modified Stover-Kincannon model in the $A_{1}$ reactor, the expression developed to assume the effluent COD concentrations was as follows:

$$
S_{\mathrm{e}-\mathrm{A}_{1}}=\frac{0.2313 S_{0-\mathrm{A}_{1}}}{6.5267 \times \frac{Q S_{0-\mathrm{A}_{1}}}{V_{\mathrm{A}_{1}}}}
$$

3.3.3 Monod-biological contact oxidation model. The Monod-BCO model was used to describe the COD removal rate of the unit area of carrier in the $\mathrm{A}_{1}$ reactor. At first, $S_{\mathrm{n}}$ needed to be evaluated by the $X$-intercept before calculating the kinetic constants due to the refractory compounds in the raw wastewater. Thus, a value of $S_{\mathrm{n}-\mathrm{A}_{1}}$ of $1050 \mathrm{mg} \mathrm{L}^{-1}$ was obtained from Fig. 4C. Furthermore, the kinetic constant for COD removal in the $\mathrm{A}_{1}$ reactor was determined from the slope line of $1 / U$ and $1 /$ $\left(S_{\mathrm{e}}-S_{0}\right)$ using eqn (22). Here, $U_{{\mathrm{m} 2-\mathrm{A}_{1}}}$ and $k_{3-\mathrm{A}_{1}}$ were determined

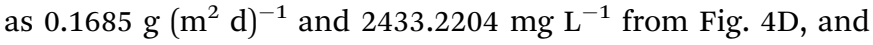
a correlation coefficient of 0.9347 was achieved. Compared to the Monod-BCO model applied in other reactors, the relatively lower value of $R^{2}$ may be due to the presence of refractory organics. The effluent COD concentration in the effluent was predicted by this model using eqn (24):

$$
S_{\mathrm{e}-\mathrm{A}_{1}}=\frac{5.934 S_{0-\mathrm{A}_{1}}-11457.615+\sqrt{\left(11457.615-5.934 S_{0-\mathrm{A}_{1}}\right)^{2}-23.734 \times\left(-8207.615 S_{0-\mathrm{A}_{1}}-3412500\right)}}{11.867}
$$

COD loading rate due to the relatively adequate degradation of organic compounds under longer HRT.

\subsection{Kinetic analyses of COD removal in the $A_{1}$ reactor}

3.3.1 Grau second-order substrate removal model. The coefficients of the Grau second-order substrate removal model in the $\mathrm{A}_{1}$ reactor were determined by plotting eqn (8). According to eqn (8), HRT/ $E$ is the slope and HRT is the intercept for the model. As shown in Fig. 4A, $a$ and $b$ were calculated as 329.7721 per day and 35.1395 per day, respectively. The determination coefficient $\left(R^{2}\right)$ of Grau second-order substrate removal in the $\mathrm{A}_{1}$ reactor was 0.8835 , revealing the unsuitability of the model. Such a lower $R^{2}$ may be due to the complexity of the raw coking wastewater, which has significant effects on the biomass concentration in the $A_{1}$ reactor because of its variable quality and toxic and harmful ingredients. Thus, $\frac{S_{0}}{k_{1} X}$ cannot be considered as an absolute constant during the operation and HRT fails to present a fine linear relationship with the HRT/E.

3.3.2 Modified Stover-Kincannon model. By applying the modified Stover-Kincannon model in the $\mathrm{A}_{1}$ reactor, the values of $k_{2-\mathrm{A}_{1}}$ and $U_{{\mathrm{m} 1-\mathrm{A}_{1}}}$ were obtained as $6.5257 \mathrm{~kg}\left(\mathrm{~m}^{3} \mathrm{~d}\right)^{-1}$ and $0.2313 \mathrm{~kg}\left(\mathrm{~m}^{3} \mathrm{~d}\right)^{-1}$, respectively, as shown in Fig. 4B. A

\subsection{Kinetic studies in the $\mathrm{A}_{2}$ reactor}

3.4.1 Grau second-order substrate removal model. As shown in Fig. 5A, the parameters of the Grau second-order model were calculated by plotting HRT/E versus HRT. It was observed that $R^{2}$ was 0.9859 , demonstrating that it was much more suitable for describing the COD performance in the $\mathrm{A}_{2}$ reactor than in the $\mathrm{A}_{1}$ reactor. Moreover, $a$ and $b$ were 7.4102 per day and 3.1057 per day, respectively.

3.4.2 Modified Stover-Kincannon model. Fig. 5B illustrates that the $R^{2}$ correlation coefficients for the modified StoverKincannon model in the $\mathrm{A}_{2}$ reactor was 0.9989 , which demonstrated that the most favorable linear relationship was between $\frac{V}{Q\left(S_{0}-S_{\mathrm{e}}\right)}$ and $\frac{V}{Q S_{0}}$ among the four reactors. It was probable that the refractory compounds were obviously reduced or converted through hydrolysis in the $\mathrm{A}_{1}$ reactor. Accordingly, sufficient and steady amounts of biodegradable COD were utilized by the denitrifying bacteria. The crucial parameters for the modified Stover-Kincannon model were confirmed, depending on eqn (11). The saturation value constant $\left(k_{2-\mathrm{A}_{2}}\right)$ and maximum utilization rate $\left(U_{{\mathrm{m} 1-\mathrm{A}_{2}}}\right)$ were calculated as $0.9522 \mathrm{~kg}\left(\mathrm{~m}^{3} \mathrm{~d}\right)^{-1}$ and $0.3385 \mathrm{~kg}\left(\mathrm{~m}^{3} \mathrm{~d}\right)^{-1}$, respectively. The equation for 

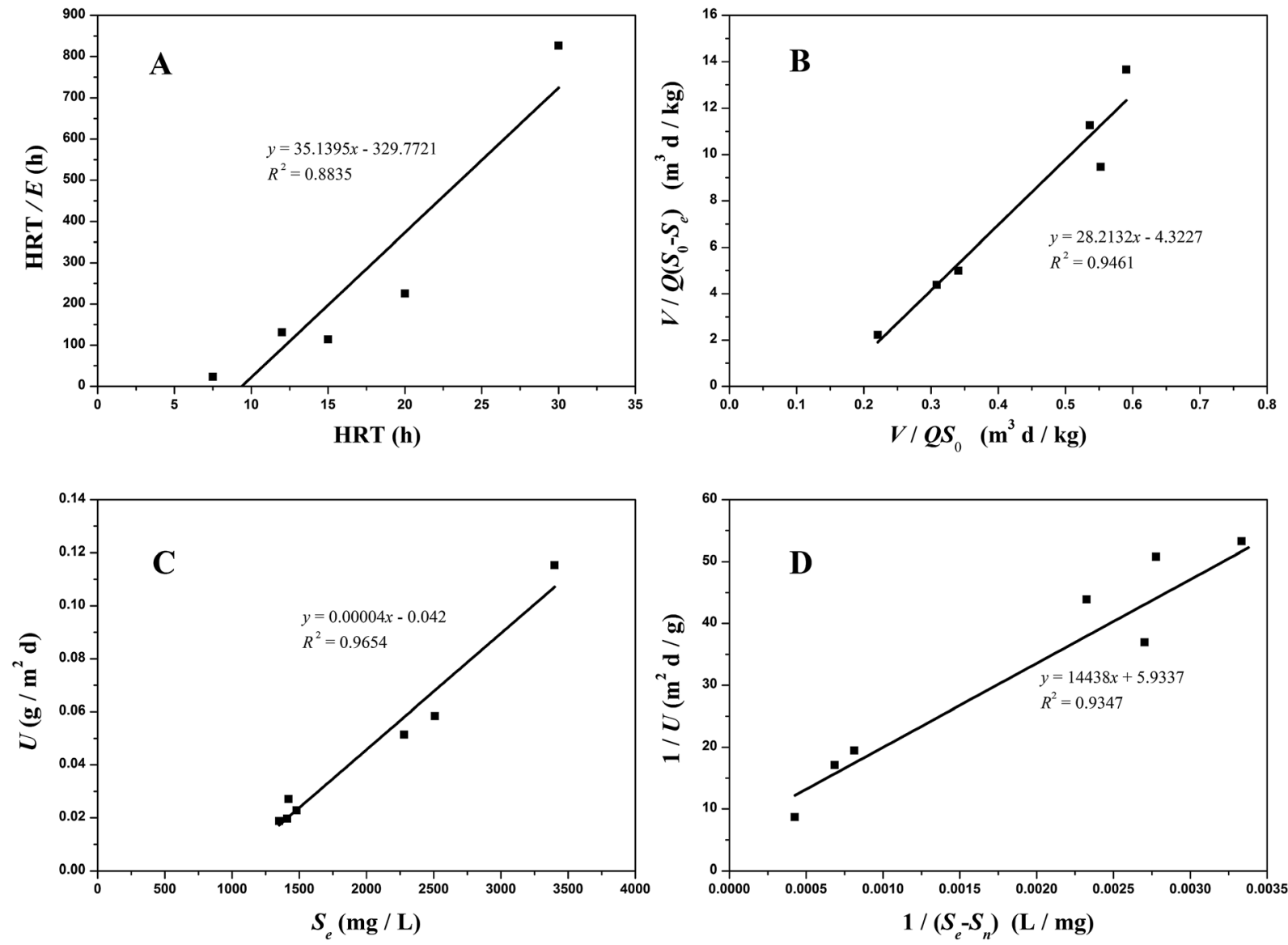

Fig. 4 Substrate removal model plots for COD removal in the $A_{1}$ reactor ( $(A)$ the Grau second-order model; (B) the modified Stover-Kincannon model; (C) $S_{n}$ calculated; (D) $U_{m}$ and $k$ calculated).

predicting the effluent COD concentrations of the $\mathrm{A}_{2}$ reactor obtained from the modified Stover-Kincannon model was as follows:

$$
S_{\mathrm{e}-\mathrm{A}_{2}}=\frac{0.3385 S_{0-\mathrm{A}_{2}}}{0.9522 \times \frac{Q S_{0-\mathrm{A}_{2}}}{V_{\mathrm{A}_{2}}}}
$$

3.4.3 Monod-biological contact oxidation model. Fig. 5C was used to determine the refractory organics $S_{\mathrm{n}-\mathrm{A}_{2}}$, which was calculated to be $105.6 \mathrm{mg} \mathrm{L}^{-1}$. Moreover, plots of $1 / U v$ s. $1 /\left(S_{\mathrm{e}}-\right.$ $S_{\mathrm{n}}$ ) are shown in Fig. 5D. The maximum rate of substrate times higher than in the $\mathrm{A}_{1}$ reactor. This may be attributed to the substantial reduction of refractory substances $S_{\mathrm{n}}$, from $1050 \mathrm{mg} \mathrm{L}^{-1}$ to $105.6 \mathrm{mg} \mathrm{L}^{-1}$ in the $\mathrm{A}_{1}$ reactor. On the other hand, along with the accumulation of $\mathrm{NO}_{x}-\mathrm{N}$ during the steadystate period in the anoxic stage, aromatics compounds with bicyclics and polycyclics were mineralized by the high concentration of denitrifying bacteria, utilizing $\mathrm{NO}_{x}-\mathrm{N}$ as substrates. ${ }^{50}$ However, the actual maximum substrate removal rate per area of carrier was $0.1044 \mathrm{~g}\left(\mathrm{~m}^{2} \mathrm{~d}\right)^{-1}$, which was only $12.45 \%$ of the predicted $U_{\mathrm{m} 2-\mathrm{A}_{2}}$, implying that the $\mathrm{A}_{2}$ reactor possessed better COD removal potential.

$$
S_{\mathrm{e}-\mathrm{A}_{2}}=\frac{1.193 S_{0-\mathrm{A}_{2}}-7088.008+\sqrt{\left(7088.008-1.193 S_{0-\mathrm{A}_{2}}\right)^{2}-4.771 \times\left(-1888.008 S_{0-\mathrm{A}_{2}}-549276\right)}}{2.385}
$$

utilization $U_{\mathrm{m} 2-\mathrm{A}_{2}}$ and the saturation concentration $\left(k_{3-\mathrm{A}_{2}}\right)$ of the Monod-BCO model were $0.8384 \mathrm{~g}\left(\mathrm{~m}^{2} \mathrm{~d}\right)^{-1}$ and $1686.5360 \mathrm{mg}$ $\mathrm{L}^{-1}$, respectively. Compared with the values obtained by the Monod-BCO model in the $A_{1}$ reactor, it can be seen that the maximum COD utilization rate in the $A_{2}$ reactor was about 5

\subsection{Kinetic studies in the $\mathrm{O}_{1}$ and $\mathrm{O}_{2}$ reactors}

3.5.1 Grau second-order substrate removal model. The Grau second-order substrate removal model was also applied to perform the COD removal in the two aerobic reactors (Fig. 6A and 7A). The values for the constant $a$ in the $\mathrm{O}_{1}$ and $\mathrm{O}_{2}$ reactors 

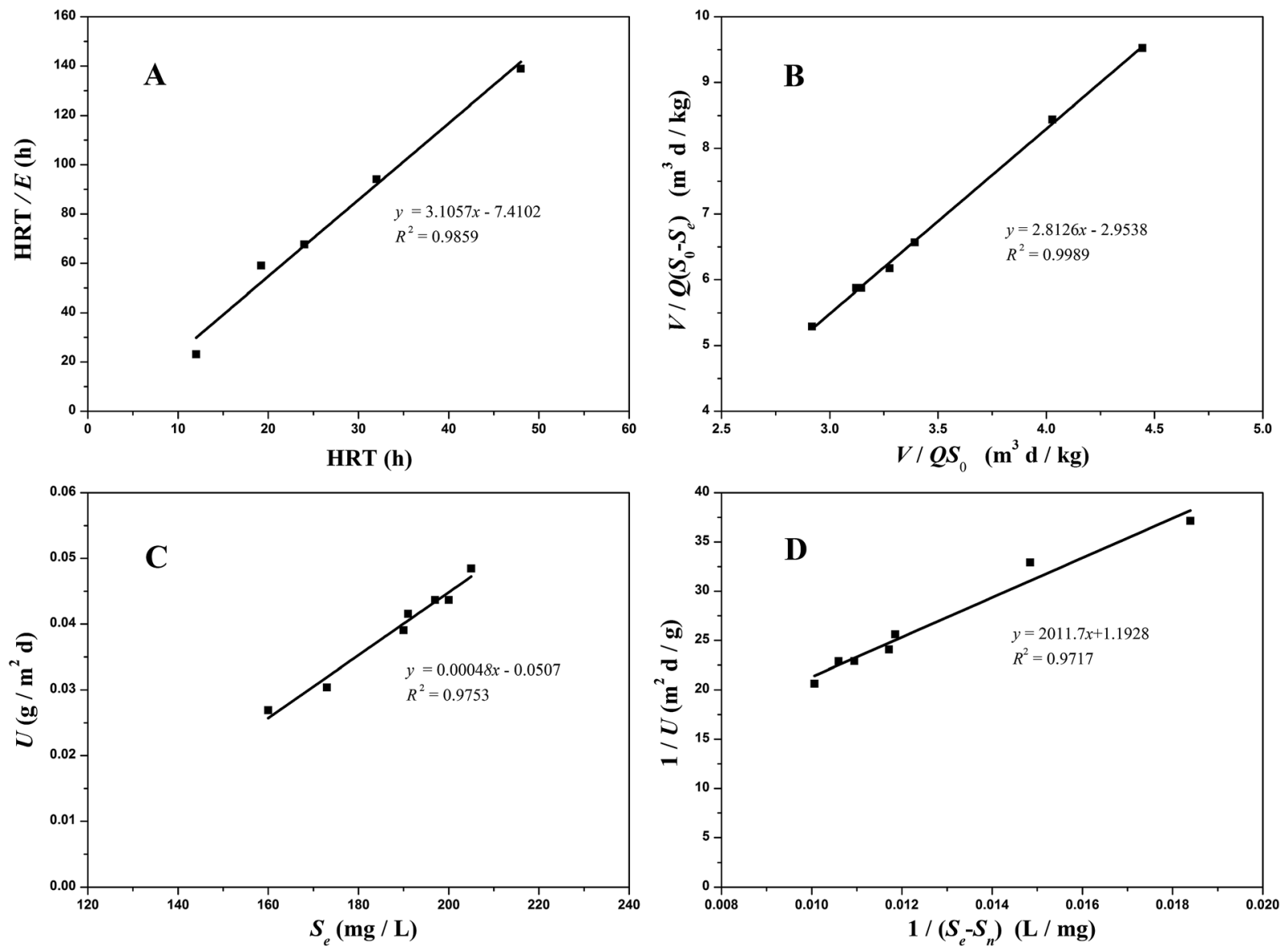

Fig. 5 Substrate removal model plots for COD removal in the $A_{2}$ reactor ((A) the Grau second-order model; (B) the modified Stover-Kincannon model; (C) $S_{n}$ calculated; (D) $U_{m}$ and $k$ calculated).

were 15.7352 per day and 47.4110 per day, respectively, while the values for constant $b$ were 3.4153 per day and 2.7484 per day, respectively. The higher correlation coefficient $\left(R^{2}=0.9527-\right.$ 0.9701 ) achieved highlighted the validity of this model in both the $\mathrm{O}_{1}$ and $\mathrm{O}_{2}$ reactors.

3.5.2 Modified Stover-Kincannon model. When the COD removal kinetics of the $\mathrm{O}_{1}$ and $\mathrm{O}_{2}$ reactors was plotted by the modified Stover-Kincannon model (Fig. 6B and 7B), best-fit lines of 0.9743 and 0.9835 were obtained, respectively.

For the $\mathrm{O}_{1}$ reactor, from the slope and intercept, the kinetic parameters for COD removal were calculated as the maximum utilization rate $U_{\mathrm{m} 1-\mathrm{O}_{1}}$ of $0.0454 \mathrm{~kg}\left(\mathrm{~m}^{3} \mathrm{~d}\right)^{-1}$ and the saturation value constant $k_{2-\mathrm{O}_{1}}$ of $0.3561 \mathrm{~kg}\left(\mathrm{~m}^{3} \mathrm{~d}\right)^{-1}$. For the $\mathrm{O}_{2}$ reactor, the model parameters evaluated were $U_{\mathrm{m} 1-\mathrm{O}_{2}}$ of $0.0308 \mathrm{~kg}\left(\mathrm{~m}^{3} \mathrm{~d}\right)^{-1}$ and $k_{2-\mathrm{O}_{2}}$ of $0.2188 \mathrm{~kg}\left(\mathrm{~m}^{3} \mathrm{~d}\right)^{-1}$, respectively. Instead of the $\mathrm{A}_{2}$ reactor with the maximum COD removal rate of $0.3385 \mathrm{~kg}\left(\mathrm{~m}^{3} \mathrm{~d}\right)^{-1}$, the COD removal efficiency of the $\mathrm{O}_{1}$ and $\mathrm{O}_{2}$ kinetic indexes decreased obviously, suggesting that the anoxic reactor significantly contributed to COD removal of the whole system. Based on the curves in Fig. $6 \mathrm{~B}$ and $7 \mathrm{~B}$, the COD concentration in the effluents from the $\mathrm{O}_{1}$ and $\mathrm{O}_{2}$ reactors by this model were simulated via utilizing eqn (27) and (28):

$$
\begin{aligned}
S_{\mathrm{e}-\mathrm{O}_{1}} & =\frac{0.0454 S_{0-\mathrm{O}_{1}}}{0.3561 \times \frac{Q S_{0-\mathrm{O}_{1}}}{V_{\mathrm{O}_{1}}}} \\
S_{\mathrm{e}-\mathrm{O}_{2}} & =\frac{0.0308 S_{0-\mathrm{O}_{2}}}{0.2188 \times \frac{Q S_{0-\mathrm{O}_{2}}}{V_{\mathrm{O}_{2}}}}
\end{aligned}
$$

3.5.3 Monod-BCO model. The Monod-BCO model coefficients in the $\mathrm{O}_{1}$ reactor were obtained from Fig. 6C and D. The value of $S_{\mathrm{n}-\mathrm{O}_{1}}$ taken from Fig. 6C was $144.12 \mathrm{mg} \mathrm{L}^{-1}$ based on eqn (21), while the numerical computation of $k_{3-\mathrm{O}_{1}}$ and $U_{\mathrm{m} 2-\mathrm{O}_{1}}$

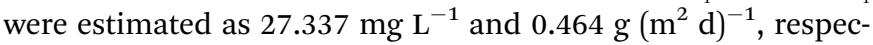
tively. The diagram displayed good co-linearity as the $R^{2}$ was 0.9728. Compared to the estimated value of $S_{\mathrm{n}-\mathrm{A}_{2}}$ obtained in the $\mathrm{A}_{2}$ reactor, the concentration of $S_{\mathrm{n}-\mathrm{O}_{1}}$ increased slightly. One of the probable explanations for this was that some chemical bonds belonging to macromolecular organic substances were not broken entirely while other organics were transformed at the same time. Zhang et al. ${ }^{9}$ also reported that some refractory substances concentration in coking wastewater increased after the anoxic reactor. In the $\mathrm{O}_{2}$ reactor, the corresponding values of $S_{\mathrm{n}-\mathrm{O}_{2}}, k_{3-\mathrm{O}_{2}}$, and $U_{\mathrm{m} 2-\mathrm{O}_{2}}$ were $49.167 \mathrm{mg} \mathrm{L}^{-1}, 1951.0162 \mathrm{mg} \mathrm{L}^{-1}$, 

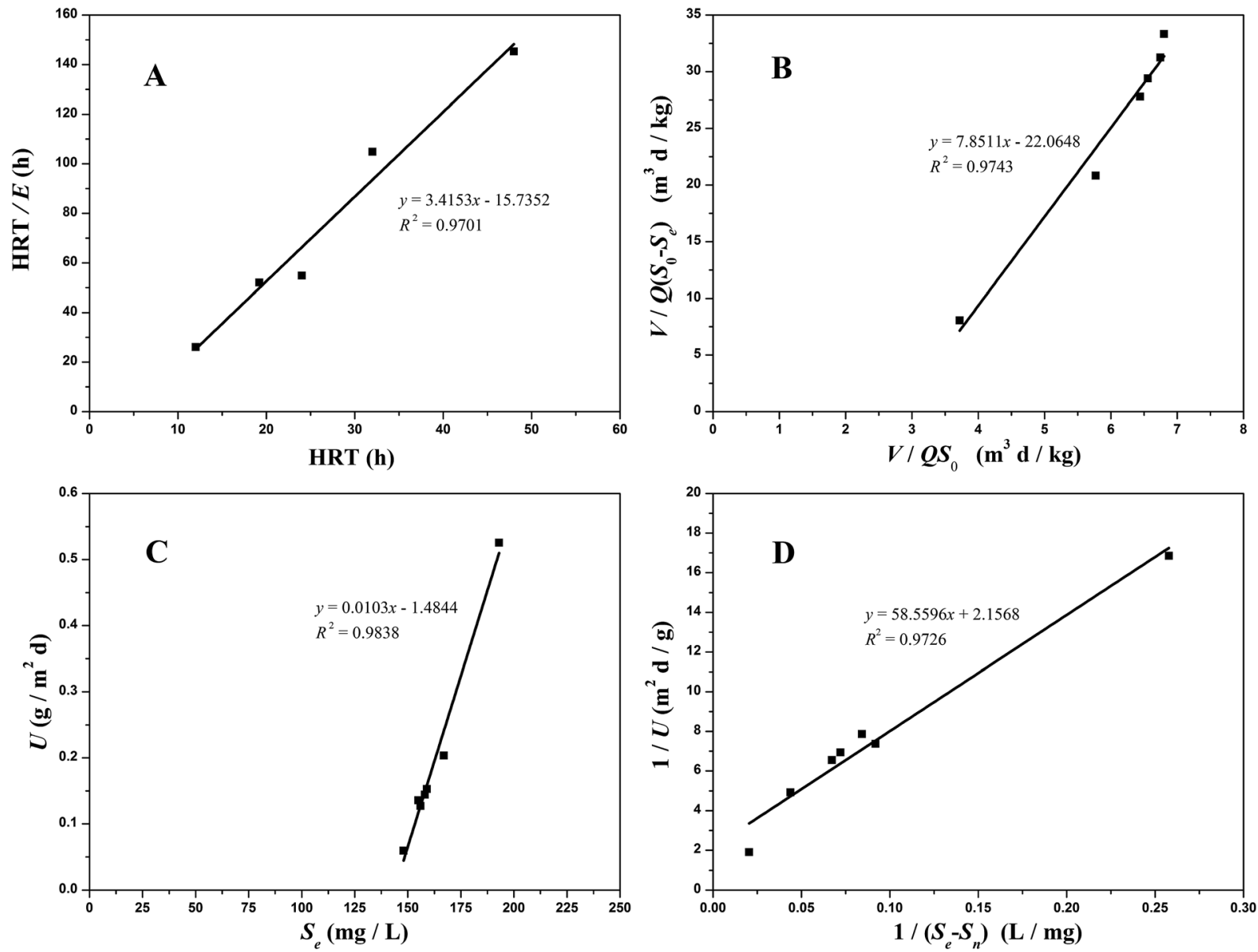

Fig. 6 Substrate removal model plots for COD removal in the $\mathrm{O}_{1}$ reactor ((A) the Grau second-order model; (B) the modified Stover-Kincannon model; (C) $S_{n}$ calculated; (D) $U_{m}$ and $k$ calculated).

and $0.2689 \mathrm{~g}\left(\mathrm{~m}^{2} \mathrm{~d}\right)^{-1}$, respectively (Fig. 7C and D). The correlation of determination was 0.9853 , thus proving the good availability of the application of the Monod-BCO model for the removal rate of COD in the $\mathrm{O}_{2}$ unit. The predicted effluent concentration of COD in the $\mathrm{O}_{1}$ and $\mathrm{O}_{2}$ reactors could be given by eqn (29) and (30), respectively:
$\mathrm{O}_{1}$ reactor, $U_{\mathrm{m}}$ in the $\mathrm{O}_{2}$ reactor was relatively low, which may be due to the presence of autotrophic nitrifying bacteria, such as nitrobacter, nitrococcus, nitrosomonas, and nitrosococcus, holding predominance in the microbial community structure in the second aerobic reactor. ${ }^{51}$ On the other hand, the inhibitory effects of the refractory organics on

$$
\begin{gathered}
S_{\mathrm{e}-\mathrm{O}_{1}}=\frac{2.144 S_{0-\mathrm{O}_{1}}-64.403+\sqrt{\left(64.403-2.144 S_{0-\mathrm{O}_{1}}\right)^{2}-8.576 \times\left(250.264 S_{0-\mathrm{O}_{1}}-45349.760\right)}}{4.288} \\
S_{\mathrm{e}-\mathrm{O}_{2}}=\frac{3.720 S_{0-\mathrm{O}_{2}}-12276.499+\sqrt{\left(12276.499-3.720 S_{0-\mathrm{O}_{2}}\right)^{2}-14.881 \times\left(-7076.499 S_{0-\mathrm{O}_{2}}-255668.400\right)}}{7.441}
\end{gathered}
$$

From the values of the maximum COD utilization rate obtained by the Monod-BCO model and the modified StoverKincannon model, it could be seen that in contrast with the microorganisms were largely reduced in the $\mathrm{O}_{2}$ reactor owing to preferential removal of the macromolecules in the first aerobic reactor. 

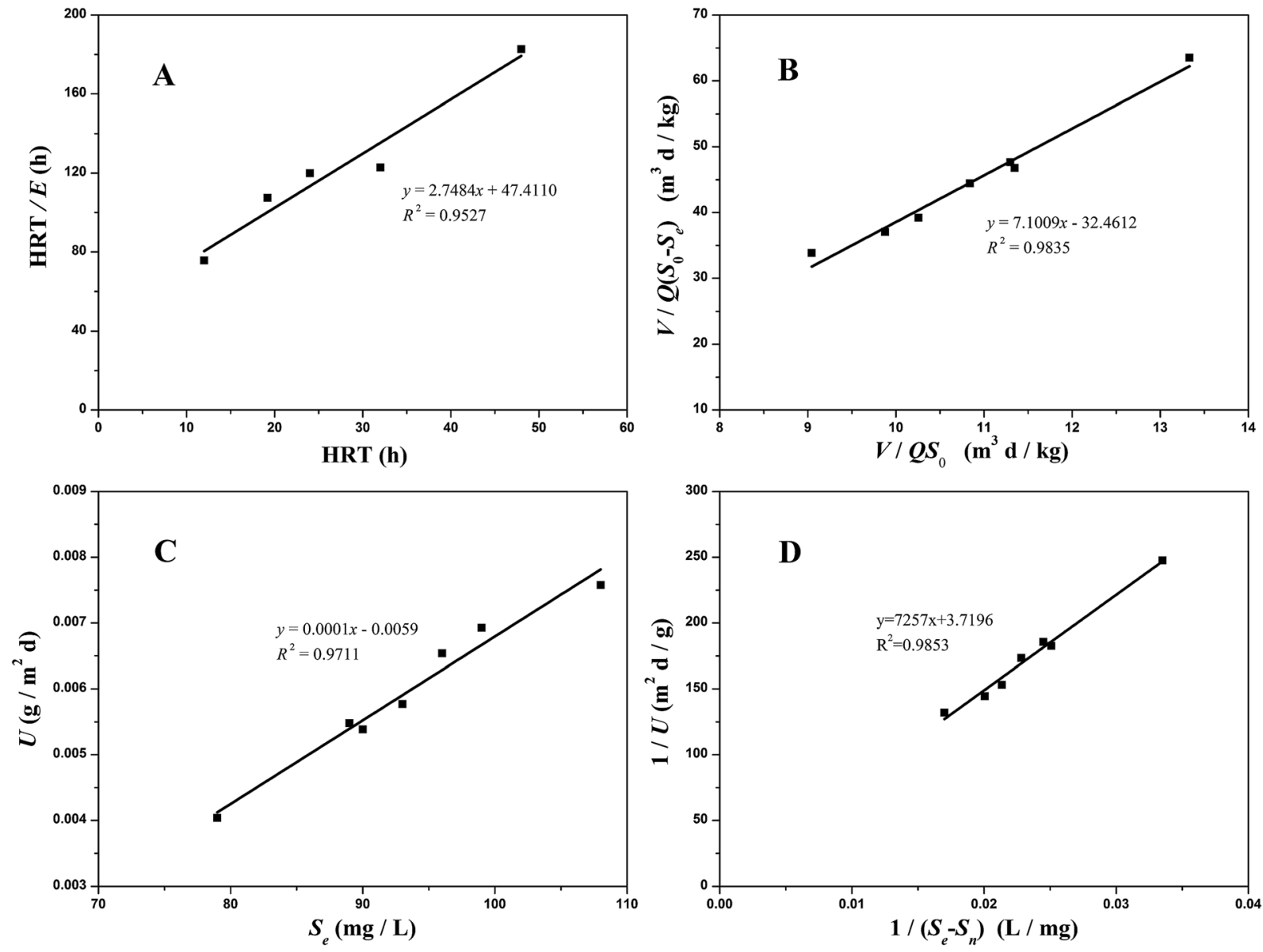

Fig. 7 Substrate removal model plots for COD removal in the $\mathrm{O}_{2}$ reactor ((A) the Grau second-order model; (B) the modified Stover-Kincannon model; (C) $S_{n}$ calculated; (D) $U_{m}$ and $k$ calculated).

\subsection{Model verifications and kinetic comparisons}

As discussed above, three kinetic models were implemented to develop a suitable model for COD removal efficiency of a multistep biofilm system. The crucial parameters obtained from the models are summarized in Table 3 . It could be observed that the modified Stover-Kincannon model and the Monod-BCO model held more advantages than the Grau second-order substrate model in predicting organics removal in the whole system. Although the Grau second-order substrate removal model was proven to have affinities with the modified Stover-Kincannon model and they converted to each other when $U_{\mathrm{m}}$ was equal to $k,{ }^{52}$ it did not perform well in the $\mathrm{A}_{1}$ reactor. The modified Stover-Kincannon model has been widely used in various reactors treating different kinds of wastewater. ${ }^{53,54}$ In this study, it also was used as a fitting precision model to describe COD removal of each unit in this system, partially owing to the addition of COD loading rate $\left(Q S_{\mathrm{i}} / V\right)$ to the model. Hence, it is capable of predicting substrate removal under any loading conditions. Furthermore, the Stover-Kincannon model did not need to consider additional hard-to-measure parameters for substrate removal prediction..$^{53}$

Table 4 gives a comparison of the kinetics results between this study and other related studies by two models. In the modified Stover-Kincannon model, from the table, it can be seen that the maximum COD removal rate $\left(U_{\max }\right)$ and the saturation constant $\left(K_{\mathrm{B}}\right)$ in this study were much lower than in other studies due to the presence of recalcitrant organics in refractory coking wastewater, similar with the value reported by Sponza et al. However, similar kinetic parameters were obtained with other related studies when utilizing the Monod model, which was the most applicable model in our study.

\subsection{Process optimization via kinetic modeling}

Although both the modified Stover-Kincannon model and the Monod-BCO model gave high correlation coefficients $\left(R^{2}>\right.$ 0.95), the Monod-BCO model was shown to be a bit more appropriate for the description of COD removal under actual conditions as the Monod-BCO model not only describes the biodegradation kinetics ${ }^{53}$ but also contains the total area of carriers and refractory compounds in its calculations. Also, the obtained Monod-BCO model could be utilized to optimize the process of the $\mathrm{FB}-\mathrm{A}^{2} / \mathrm{O}^{2}$ system treating coking wastewater. The value of the half-saturation constant $(k)$ could represent the substrate affinity, which means a higher COD removal efficiency when higher $k$ values are obtained. The $k$ values obtained by the Monod-BCO model of a biofilm for the $\mathrm{A}_{1}, \mathrm{~A}_{2}, \mathrm{O}_{1}$, and $\mathrm{O}_{2}$ 
Table 3 Summary of kinetic constants in the different reactors

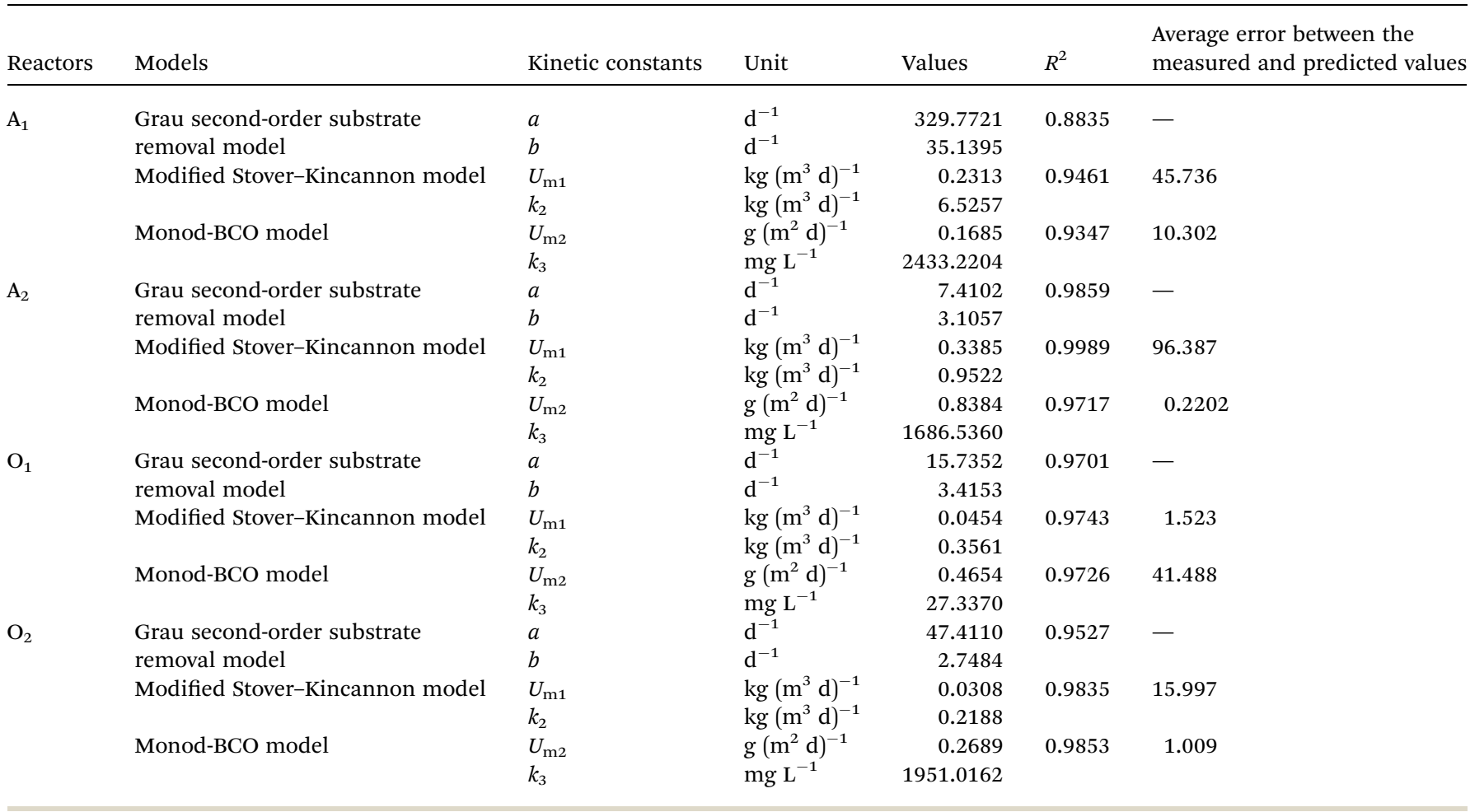

reactors were $2433.2204 \mathrm{mg} \mathrm{L}^{-1}, 1686.5360 \mathrm{mg} \mathrm{L}^{-1}, 27.3370 \mathrm{mg}$ $\mathrm{L}^{-1}$, and $1951.0162 \mathrm{mg} \mathrm{L}^{-1}$, respectively. Compared with the previously reported values for coking wastewater treatment, ${ }^{23,59}$ our system had significantly higher substrate affinity in this study. The average $k$ value obtained in this study was $1524.527 \mathrm{mg} \mathrm{L}^{-1}$, which was higher than the COD concentration in raw coke plant wastewater. It was certificated that the pilot- scale $\mathrm{A}^{2} / \mathrm{O}^{2}$ biofilm system had a maximum potential of COD removal efficiency; that is, the effluent COD concentration set by the system could be much lower than the presented result. Moreover, the actual average COD removal rate per area of the carrier could not completely reach the predicted $U_{\mathrm{m}}$ value in the system (only about $19.18 \%$ of the $U_{\mathrm{m}}$ ). This may partially be attributed to an undesirable substrate distribution, especially in

Table 4 Kinetic comparisons of this study and other related studies

\begin{tabular}{|c|c|c|c|c|c|c|c|}
\hline Model & Wastewater & Process & COD mg $\mathrm{L}^{-1}$ & OLR $\mathrm{kg} \mathrm{m}^{-3} \mathrm{~d}^{-1}$ & $U_{\max } \mathrm{kg} \mathrm{m}^{-3} \mathrm{~d}^{-1}$ & $K_{\mathrm{B}} \mathrm{kg} \mathrm{m}^{-3} \mathrm{~d}^{-1}$ & References \\
\hline \multirow[t]{5}{*}{$\begin{array}{l}\text { Modified } \\
\text { Stover- } \\
\text { Kincannon }\end{array}$} & Distillery spent wash & $\begin{array}{l}\text { Anaerobic } \\
\text { fixed film } \\
\text { bioreactor }\end{array}$ & $11000-19000$ & $5-20$ & 2 & 1.69 & 55 \\
\hline & 2,4-DCP wastewater & UASB & 3000 & $3.6-36$ & 0.008 & 0.0346 & 56 \\
\hline & $\begin{array}{l}\text { Weak industrial } \\
\text { wastewater }\end{array}$ & UASB & $704.55 \pm 54.33$ & $0.8052-0.049$ & 1.502 & 2.924 & 57 \\
\hline & & Oxic-1 & & & 0.0454 & 0.3561 & \\
\hline & & Oxic-2 & & & 0.0308 & 0.2188 & \\
\hline Model & Wastewater & Process & COD mg L ${ }^{-1}$ & OLR $\mathrm{kg} \mathrm{m}^{-3} \mathrm{~d}^{-1}$ & $U_{\max } \mathrm{kg} \mathrm{m}^{-3} \mathrm{~d}^{-1}$ & $K_{\mathrm{B}} \mathrm{mg} \mathrm{L}^{-1}$ & References \\
\hline \multirow[t]{3}{*}{ Monod } & 2,4-DCP wastewater & UASB & 3000 & $6-34$ & 2.73 & 560 & 56 \\
\hline & & Oxic-1 & & & 0.1098 & 27.337 & \\
\hline & & Oxic-2 & & & 1.0487 & 1951.0162 & \\
\hline
\end{tabular}


the $\mathrm{O}_{2}$ reactor. Uneven organics provision led to a decreased utilized rate of the carbon source. Moreover, many studies have reported that some non-biodegradable organic compounds, like NHCs, in anaerobic or aerobic units tend to be easily mineralized under anoxic conditions. From this perspective, the potentials of the $\mathrm{A}_{2}, \mathrm{O}_{1}$, and $\mathrm{O}_{2}$ reactors' degradation for COD might not be made full use of in single-feeding systems, since all raw wastewater only directly flows into the anaerobic tank. To ensure the combined biodegradation of organics under different redox conditions to enhance the process for COD removal, a step-feeding process is expected to be an alternative option. However, studies on the flow distributed ratio within each reactor also should be further optimized in any stepfeeding process in the future.

\section{Conclusion}

In this study, the COD removal characteristics and biokinetics models of this were investigated utilizing a pilot-scale $\mathrm{FB}-\mathrm{A}^{2} / \mathrm{O}^{2}$ system effectively treating high-strength coking wastewater. Some conclusions were drawn, as listed below:

(1) The COD removal rate increases and then flattens with the increase in the influent COD loading rate. The maximum COD removal efficiency achieved was $92.3 \%$ with an effluent COD concentration of $98 \mathrm{mg} \mathrm{L}^{-1}$ at an OLR of $0.25 \mathrm{~kg}\left(\mathrm{~m}^{3} \mathrm{~d}\right)^{-1}$. The results indicated that the anoxic and first oxic units played significant roles in removing the COD from coking wastewater.

(2) The modified Stover-Kincannon model and Monodbiological contact oxidation model were proven to be applicable to estimate the COD removal performance in each unit. Model validation demonstrated that the Monod-BCO model fitted better for COD removal, even though the modified StoverKincannon model had a higher correlation coefficient. According to the Monod-BCO model, The theoretical COD maximum removal rates $\left(U_{\mathrm{m}}\right)$ of the $\mathrm{A}_{1}, \mathrm{~A}_{2}, \mathrm{O}_{1}$, and $\mathrm{O}_{2}$ units were $0.1685 \mathrm{~g}$ $\left(\mathrm{m}^{2} \mathrm{~d}\right)^{-1}, 0.8384 \mathrm{~g}\left(\mathrm{~m}^{2} \mathrm{~d}\right)^{-1}, 0.4654 \mathrm{~g}\left(\mathrm{~m}^{2} \mathrm{~d}\right)^{-1}$, and $0.2689 \mathrm{~g}\left(\mathrm{~m}^{2}\right.$ $\mathrm{d})^{-1}$, respectively, and a large amount of refractory substance $\left(S_{\mathrm{n}}\right)$ could be decreased through utilizing the system.

(3) The system also showed great substrate affinity, whereby the corresponding $k$ values of each rector were $2433.2204 \mathrm{mg}$ $\mathrm{L}^{-1}, 1686.5360 \mathrm{mg} \mathrm{L}^{-1}, 27.3370 \mathrm{mg} \mathrm{L}^{-1}$, and $1951.0162 \mathrm{mg} \mathrm{L}^{-1}$, respectively.

(4) Step-feeding after the $A_{1}$ reactor was suggested to optimize the system on the basis of the Monod-BCO kinetic model in this study.

\section{Acknowledgements}

This work was supported by National Natural Science Foundation of Youth in China (No. 21607111), China Postdoctoral Science Foundation (No. 2015M571287), Open project in State Key Laboratory of Urban Water Resources and Environment, Harbin Institute of Technology (No. QA201620) and Graduate Students Joint Training Base for Talents Training Project in Shanxi (No. 2016JD16). The authors also thank Dr David Howard for English language editing of this manuscript.

\section{References}

1 M. Han, G. Li, N. Sang and Y. Dong, Investigating the biotoxicity of coking wastewater using Zea mays L. assay, Ecotoxicol. Environ. Saf., 2011, 74, 1050-1056.

2 S. Zhou, H. Watanabe, C. Wei, D. Wang, J. Zhou, N. Tatarazako, S. Masunaga and Y. Zhang, Reduction in toxicity of coking wastewater to aquatic organisms by vertical tubular biological reactor, Ecotoxicol. Environ. Saf., 2015, 115, 217-222.

3 E. I. Garcia-Pena, P. Zarate-Segura, P. Guerra-Blanco, T. Poznyak and I. Chairez, Enhanced Phenol and Chlorinated Phenols Removal by Combining Ozonation and Biodegradation, Water, Air, Soil Pollut., 2012, 223, 4047-4064.

4 G. Moussavi and M. Heidarizad, The performance of SBR, SCR, and MSCR for simultaneous biodegradation of high concentrations of formaldehyde and ammonia, Sep. Purif. Technol., 2011, 77, 187-195.

5 P. Xu, H. Han, H. Zhuang, B. Hou, S. Jia, D. Wang, K. Li and Q. Zhao, Anoxic degradation of nitrogenous heterocyclic compounds by activated sludge and their active sites, $J$. Environ. Sci., 2015, 31, 221-225.

6 W. Zhang, C. Wei, B. Yan, C. Feng, G. Zhao, C. Lin, M. Yuan, C. $\mathrm{Wu}, \mathrm{Y}$. Ren and Y. Hu, Identification and removal of polycyclic aromatic hydrocarbons in wastewater treatment processes from coke production plants, Environ. Sci. Pollut. Res. Int., 2013, 20, 6418-6432.

7 X. Yu, C. Wei, H. Wu, Z. Jiang and R. Xu, Improvement of biodegradability for coking wastewater by selective adsorption of hydrophobic organic pollutants, Sep. Purif. Technol., 2015, 151, 23-30.

8 P. Lai, H. Z. Zhao, M. Zeng and J. R. Ni, Study on treatment of coking wastewater by biofilm reactors combined with zerovalent iron process, J. Hazard. Mater., 2009, 162, 1423-1429.

9 M. Zhang, J. H. Tay, Y. Qian and X. S. Gu, Coke plant wastewater treatment by fixed biofilm system for COD and $\mathrm{NH}_{3}-\mathrm{N}$ removal, Water Res., 1998, 32, 519-527.

10 H.-q. Li, H.-j. Han and M.-a. Du, Effect of nitrate concentration on performance of pre-denitrification moving bed biofilm reactor system in treating coal gasification wastewater, Desalin. Water Treat., 2013, 51, 5996-6002.

11 X. Yuan, H. Sun and D. Guo, The removal of COD from coking wastewater using extraction replacementbiodegradation coupling, Desalination, 2012, 289, 45-50.

12 Q. Gu, T. Sun, G. Wu, M. Li and W. Qiu, Influence of carrier filling ratio on the performance of moving bed biofilm reactor in treating coking wastewater, Bioresour. Technol., 2014, 166, 72-78.

13 J. Y. Jing, J. Feng, W. Y. Li and Y. Xu, Removal of COD from coking-plant wastewater in the moving-bed biofilm sequencing batch reactor, Korean J. Chem. Eng., 2009, 26, 564-568.

14 P. Lai, H. Zhao, Z. Ye and J. Ni, Assessing the effectiveness of treating coking effluents using anaerobic and aerobic biofilms, Process Biochem., 2008, 43, 229-237. 
15 L. Rodríguez-Hernández, A. L. Esteban-García and I. Tejero, Comparison between a fixed bed hybrid membrane bioreactor and a conventional membrane bioreactor for municipal wastewater treatment: A pilot-scale study, Bioresour. Technol., 2014, 152, 212-219.

$16 \mathrm{Z}$. Yu, Treatment of coke plant wastewater by A/O fixed biofilm system, Sci. China, Ser. B: Chem., 2005, 48, 489-496.

17 S. Shi, Y. Qu, Q. Ma, X. Zhang, J. Zhou and F. Ma, Performance and microbial community dynamics in bioaugmented aerated filter reactor treating with coking wastewater, Bioresour. Technol., 2015, 190, 159-166.

18 P. M. Sutton and M. Hoeksema, Biological fluidized-bed treatment of wastewater from byproduct coking operations: Full-scale case history, Water Environ. Res., 1999, 71, 5-9.

19 H. S. Ou, C. H. Wei, H. Z. Wu, C. H. Mo and B. Y. He, Sequential dynamic artificial neural network modeling of a full-scale coking wastewater treatment plant with fluidized bed reactors, Environ. Sci. Pollut. Res. Int., 2015, 22, 15910-15919.

$20 \mathrm{~S}$. Zhu and J. Ni, Treatment of coking wastewater by a UBFBAF combined process, J. Chem. Technol. Biotechnol., 2008, 83, 317-324.

21 B. P. Sahariah, J. Anandkumar and S. Chakraborty, Treatment of coke oven wastewater in an anaerobicanoxic-aerobic moving bed bioreactor system, Desalin. Water Treat., 2015, 57, 14396-14402.

22 X. Zhou, Y. Li, Y. Zhao and X. Yue, Pilot-scale anaerobic/ anoxic/oxic/oxic biofilm process treating coking wastewater, J. Chem. Technol. Biotechnol., 2013, 88, 305-310.

23 X. Wu, Y. Yang, G. Wu, J. Mao and T. Zhou, Simulation and optimization of a coking wastewater biological treatment process by activated sludge models (ASM), J. Environ. Manage., 2016, 165, 235-242.

24 M. K. Sharma and A. A. Kazmi, Substrate Removal Kinetics of Domestic Wastewater Treatment in a Two-Stage Anaerobic System, Sep. Sci. Technol., 2015, 50, 2752-2758.

25 E. Debik and T. Coskun, Use of the Static Granular Bed Reactor (SGBR) with anaerobic sludge to treat poultry slaughterhouse wastewater and kinetic modeling, Bioresour. Technol., 2009, 100, 2777-2782.

26 L. Sun, S. Wan, Z. Yu, Y. Wang and S. Wang, Anaerobic biological treatment of high strength cassava starch wastewater in a new type up-flow multistage anaerobic reactor, Bioresour. Technol., 2012, 104, 280-288.

27 J. Monod, The Growth of Bacterial Cultures, Annu. Rev. Microbiol., 1949, 3, 371-394.

28 T. Chen, P. Zheng, L. Shen, S. Ding and Q. Mahmood, Kinetic characteristics and microbial community of Anammox-EGSB reactor, J. Hazard. Mater., 2011, 190, 28-35.

29 C. T. Goudar and T. G. Ellis, Explicit oxygen concentration expression for estimating extant biodegradation kinetics from respirometric experiments, Biotechnol. Bioeng., 2001, 75, 74-81.

30 A. O. Ibeje, Mathematical Modelling of Cassava Wastewater Treatment Using Anaerobic Baffled Reactor, Am. J. Eng. Res., 2013, 2, 128-134.
31 S. Macé, J. Dosta, A. Galí and J. Mata-Alvarez, Optimization of Biological Nitrogen Removal via Nitrite in a SBR Treating Supernatant from the Anaerobic Digestion of Municipal Solid Wastes, Ind. Eng. Chem. Res., 2006, 45, 2787-2792.

32 Z. Y. Pan, S. Q. Yu and H. F. Huang, Treatment of high concent ration pesticide wastewater by pressurized biochemical process, The 10th Asia Pacific Confederation of Chemical Engineering Congress, Japan, 2004, pp. 128-135.

$33 \mathrm{~J}$. C. $\mathrm{Hu}$ and X. S. Gu, Research on the kinetic model of wastewater treatment by using the bio-contact oxidation, China Water Wastewater, 1987, 5-9.

34 E. L. Stover and D. F. Kincannon, Presented in Part at the Proceedings of the 1st International Conference on Fixed Film Biological Processes, Ohio, 1982.

35 S. Sandhya and K. Swaminathan, Kinetic analysis of treatment of textile wastewater in hybrid column upflow anaerobic fixed bed reactor, Chem. Eng. J., 2006, 122, 87-92.

36 A. Noroozi, M. Farhadian and A. Solaimanynazar, Kinetic coefficients for the domestic wastewater treatment using hybrid activated sludge process, Desalin. Water Treat., 2014, 57, 4439-4446.

37 J. Wang, J. Yan and W. Xu, Treatment of dyeing wastewater by MIC anaerobic reactor, Biochem. Eng. J., 2015, 101, 179184.

38 S. A. Kordkandi and L. Berardi, Comparing new perspective of hybrid approach and conventional kinetic modelling techniques of a submerged biofilm reactor performance, Biochem. Eng. J., 2015, 103, 170-176.

39 A. Akhbari, A. A. L. Zinatizadeh, P. Mohammadi, Y. Mansouri, M. Irandoust and M. H. Isa, Kinetic modeling of carbon and nutrients removal in an integrated rotating biological contactor-activated sludge system, Int. J. Environ. Sci. Technol., 2012, 9, 371-378.

40 J. H. Ahn and C. F. Forster, Kinetic analyses of the operation of mesophilic and thermophilic anaerobic filters treating a simulated starch wastewater, Process Biochem., 2000, 36, 19-23.

41 M. Faridnasr, B. Ghanbari and A. Sassani, Optimization of the moving-bed biofilm sequencing batch reactor (MBSBR) to control aeration time by kinetic computational modeling: Simulated sugar-industry wastewater treatment, Bioresour. Technol., 2016, 208, 149-160.

42 W. Y. Li, P. M. Xu, Y. Xu and J. Y. Jing, Study on Kinetic Model of Immobilized Dominant Bacteria for Treatment of COD in Coke Plant Wastewater, Energy Sources, Part A, 2009, 31, 1654-1659.

43 P. Grau, M. Dohányos and J. Chudoba, Kinetics of multicomponent substrate removal by activated sludge, Water Res., 1975, 9, 637-642.

44 S. M. Borghei, M. Sharbatmaleki, P. Pourrezaie and G. Borghei, Kinetics of organic removal in fixed-bed aerobic biological reactor, Bioresour. Technol., 2008, 99, 1118-1124.

$45 \mathrm{H}$. Yu, F. Wilson and J.-H. Tay, Kinetic analysis of an anaerobic filter treating soybean wastewater, Water Res., 1998, 32, 3341-3352. 
46 Standard Monitoring \& Analytical Methods for the Examination of Water and Wastewater, ed. E. P. A. Chinese, China Environmental Science Press, Beijing, 2002.

47 E. Maranon, I. Vazquez, J. Rodriguez, L. Castrillon, Y. Fernandez and H. Lopez, Treatment of coke wastewater in a sequential batch reactor (SBR) at pilot plant scale, Bioresour. Technol., 2008, 99, 4192-4198.

48 X. L. Shi, X. B. Hu, Z. Wang, L. L. Ding and H. Q. Ren, Effect of reflux ratio on COD and nitrogen removals from coke plant wastewaters, Water Sci. Technol., 2010, 61, 3017-3025.

49 X. X. Wei, Z. Y. Zhang, Q. L. Fan, X. Y. Yuan and D. S. Guo, The effect of treatment stages on the coking wastewater hazardous compounds and their toxicity, J. Hazard. Mater., 2012, 239-240, 135-141.

50 K. J. Rockne and S. E. Strand, Anaerobic biodegradation of naphthalene, phenanthrene, and biphenyl by a denitrifying enrichment culture, Water Res., 2001, 35, 291-299.

51 X. Zhou, Y. X. Li and Y. Zhao, Removal characteristics of organics and nitrogen in a novel four-stage biofilm integrated system for enhanced treatment of coking wastewater under different HRTs, RSC Adv., 2014, 4, 15620-15629.

52 M. Işik and D. T. Sponza, Substrate removal kinetics in an upflow anaerobic sludge blanket reactor decolorising simulated textile wastewater, Process Biochem., 2005, 40, 1189-1198.
53 S. Q. Ni, S. Sung, Q. Y. Yue and B. Y. Gao, Substrate removal evaluation of granular anammox process in a pilot-scale upflow anaerobic sludge blanket reactor, Ecol. Eng., 2012, 38, 30-36.

54 X. W. Huang, Q. Y. Wei, K. Urata, Y. Tomoshige, X. H. Zhang and Y. Kawagoshi, Kinetic study on nitrogen removal performance in marine anammox bacterial culture, $J$. Biosci. Bioeng., 2014, 117, 285-291.

55 B. K. Acharya, H. Pathak, S. Mohana, Y. Shouche, V. Singh and D. Madamwar, Kinetic modelling and microbial community assessment of anaerobic biphasic fixed film bioreactor treating distillery spent wash, Water Res., 2011, 45, 4248-4259.

56 D. T. Sponza and A. Ulukoy, Kinetic of carbonaceous substrate in an upflow anaerobic sludge sludge blanket (UASB) reactor treating 2,4-dichlorophenol (2,4-DCP), $J$. Environ. Manage., 2008, 86, 121-131.

57 S. M. Abtahi, M. M. Amin, R. Nateghi and A. Vosoogh, Prediction of effluent COD concentration of UASB reactor using kinetic models of Monod, Contois, second-order Grau and modified Stover-Kincannon, Int. J. Environ. Health Eng., 2013, 2, 12.

58 M. Vuković, I. Ćosić and D. Kučić, Biodegradation kinetics of tobacco waste leachate by activated sludge in SBR, Chem. Biochem. Eng. Q., 2012, 26, 191-198.

59 C. J. Dong and Q. Y. Pan, Kinetic Analysis for COD Removal in Actual Coking Wastewater through an Micro-Aerobic EGSB Reactor, Appl. Mech. Mater., 2014, 700, 455-459. 